\title{
Serum immunoglobulin levels in patients with lymphoproliferative diseases in Erbil, Kurdistan region, Iraq
}

\begin{abstract}
Background and objectives: Lymphoproliferative neoplasms are among the commonest human neoplasia. Immune dysregulation is frequently associated with many of these diseases, particularly those related to B-cell origin. This study aimed to find out the immunological status of newly diagnosed patients with lymphoproliferative disorders.

Methods: This study was carried out in Erbil province during the period from November 2010 to April 2011. Fifty two newly diagnosed patients (34 males and 18 females) with lymphoproliferative disorders referred to Nnakaly Hospital for blood disease and 20 healthy control subjects had been included in this study. Determination of immunoglobulin subclasses by radial immunodiffusion in addition serum protein electrophoresis has been performed for each sample for the detection of monoclonal bands.

Results: Serum IgM and IgA level were decreased in all groups of patients with different lymphoproliferative disorders compared to control group. Serum IgG level showed insignificant reduction in acute lymphocytic leukemia and chronic lymphocytic leukemia patients, but it was increased in non Hodgkin lymphoma, Hodgkin lymphoma and multiple myeloma patients. Paraproteinemia had been seen in all patients with multiple myeloma while only $10 \%$ of chronic lymphocytic leukemia and non Hodgkin lymphoma showed paraproteinemia. No M-band had been noticed in acute lymphocytic leukemia and Hodgkin lymphoma.
\end{abstract}

Conclusion: There were some conflicting data regarding serum immunoglobulin levels in newly diagnosed patients with lymphoproliferative disorders in Erbil, Iraq.

Keywords: Lymphoproliferative disorders; Immunoglobulin; Paraprotein.

\section{Introduction}

Acute lymphoblastic leukemia (ALL) is a malignant neoplasm of lymphocytes characterized by the clonal accumulation of immature blood cells in the BM. These abnormal cells are arrested in the lymphoblast stage of the normal maturation pathway. ${ }^{1}$ Chronic lymphoblastic leukemia (CLL) is a neoplastic disease characterized by the accumulation of small, matureappearing lymphocytes in the blood, marrow, and lymphoid tissues. ${ }^{2}$ NonHodgkin's lymphomas (NHL) are tumors of the immune system causing very often the alteration of immune function in affected patients which is not surprising because one function of the immune system is the production and secretion of immunoglobulin molecules. Immunoglobulin production depends on normal B- and T-cell interactions and may be estimated by measuring serum immunoglobulin levels. ${ }^{3}$ Multiple myeloma $(\mathrm{MM})$ is a B-cell malignancy characterized by a monoclonal expansion and accumulation of abnormal plasma cells in the bone marrow compartment. ${ }^{4}$ Normal adult has some preexisting $B$ lymphocytes that can produce an immunoglobulin that can bind almost any foreign antigen. Such B cells can be recruited to the immune response against the antigen. In the presence of accessory T-follicular helper cells, an antigen-binding clone of

* Directorate of Health, Erbil, Iraq.

** Department of Clinical Analysis, College of Pharmacy, Hawler Medical University, Erbil, Iraq. 
B lymphocytes may transform into antibody -secreting plasma cells. An important factor in plasma cell differentiation is the B-lymphocyte-induced maturation protein-1 (Blimp-1). ${ }^{5}$ Some studies have revealed an increased activity, number, and differentiation of B lymphocytes. In different studies, IgA and IgG serum levels have been reported normal to high, ${ }^{7}$ while IgM level was normal or decreased. ${ }^{6}$ Hematologic malignancies and their treatment are among important causes of secondary immunodeficiency. The majority of the affected patients do not have the previous immunodeficiency. However, development of malignancies such as leukemia could indicate a dysregulation in the immune system. ${ }^{8}$ Different studies have evaluated quantitative and qualitative immunologic variables in malignancies. All have conflicting results. Serum immunoglobulin level is a parameter which seems to be abnormal in few patients with hematologic malignancies. ${ }^{9}$ This study aimed to find out the immunological status of newly diagnosed patients with lymphoproliferative disorders.

\section{Methods}

This study was carried out in Erbil province during the period from November 2010 to April 2011. Fifty two (34 males and 18 females) newly diagnosed patients with lymphoproliferative disorders referred to Nanakaly Hospital for blood disease and 20 healthy control subjects had been included in this study. Venous blood samples were obtained from enrolled patients with venipuncture. Five milliliters were withdrawn from each patient and control group; the blood was collected into sterile plain tubes and left for 30 minutes at room temperature to clot. Then it was centrifuged at 2500 RPM for $10 \mathrm{~min}$; the serum was separated and transferred into sterile screw capped labeled tubes and stored at $-20 \mathrm{C}^{\circ}$ for the later determination of immunoglobulin subclasses by single radial immunodiffusion in addition serum protein electrophoresis has been performed for each sample for the detection of monoclonal bands. Data were evaluated statistically, analyzed and organized into tables and graphs. The computer program software the statistical package for the social sciences (version 14) was used to analyze the data. Quantitative variables were compared using the Student's t-test. Results were considered significant if the $P$ value was less than 0.05 .

Quantitative estimation of serum Immunoglobulins (IgG, IgM, and IgA classes) by Single Radial Immunodiffusion (SRID) assay:

\section{The Procedure:}

1- The plate was removed from its envelope and left to stand at room temperature for few minutes so that any condensed water in the wells can evaporate.

2- The IgG plate (containing 15 wells of Anti-lgG) were filled with $5 \mu$ of the serum and waiting for few minutes for good adsorption before handling the plate.

3- The plate was closed and placed in a moist chamber (refrigerator).

4- After incubation period for 72 hours, a clear circle was surrounded each well in the plate after diffusion. The circle diameter was measured to nearest $0.1 \mathrm{~mm}$ with suitable immune viewer then compared with the standard table provided with the leaflet and recorded by World Health Organization (WHO).

* Similar procedure was applied for the measurement of serum IgM with the exception that plate of IgM (containing 15 wells of Anti-lgM) were filled with $5 \mu$ l of the patient's serum.

** Similar procedure was applied for the measurement of serum $\lg A$ with the exception that plate of IgA (containing 15 wells of Anti-IgA) were filled with $5 \mu$ of the patient's serum.

\section{Serum protein electrophoresis Procedure}

1- A cellulose acetate strip was labeled with a pencil for application of samples and control spots. 
2- The strip was impregnated with buffer by floating it on the surface of the buffer solution in a flat dish, a few seconds later the strip was immersed completely for 10 seconds.

3- The strip was placed on the shoulder pieces of the tank.

4- $5 \mu \mathrm{l}$. of each sample was applied.

5- A constant voltage (150 Volt) with

a constant current was connected for 35 minutes.

6- The current was turned off.

7- Carefully the strip was removed and dried, then transferred into staining solution which contained TCA to fix the protein and ponceau $S$ to visualize the individual protein bands.

8- The excess dye was removed out by washing solution.

9- The strip was placed in a clearing agent (10\% paraffin oil).

10- The protein bands were quantified by a densitometer.

\section{Results}

Acute Lymphoblastic Leukemia:

The mean concentration of serum $\operatorname{lgG}$, $\lg \mathrm{M}$ and $\lg \mathrm{A}$ were 1082.5, 105 and 115.4 respectively, the mean concentration of $\lg$, IgM and $\lg A$ were $1156.95,147.25$ and $215.75 \mathrm{mg} / \mathrm{dl}$ respectively in control groups. Compared to control group the decrease in IgA level was highly significant $(P<0.01)$, IgM was reduced significantly $(P<0.05)$, while the reduction in IgG level didn't reach a significant level (Table 1).

\section{Chronic Lymphoblastic Leukemia}

The mean value of $\lg G, \lg M$ and $\lg A$ in newly diagnosed patients with CLL were 896.2, 61.4 and $161.4 \mathrm{mg} / \mathrm{dl}$ respectively, the mean value of these parameters among control groups were 1156.95, 147.25 and $215.75 \mathrm{mg} / \mathrm{dl}$ respectively. As it is illustrated in Table 2, the mean value of all immunoglobulins ( $\lg G, \lg M$ and $\lg A$ ) decreased in the patients compared to the control but the IgM decrease was highly significant $(P<0.01)$.

\section{Non Hodgkin Lymphoma}

The mean concentration of $\operatorname{lgG}$, IgM and IgA were $1210.3,98.5$ and $176.2 \mathrm{mg} / \mathrm{dl}$ respectively, as it is clear in Table 3 , IgM decreased significantly, while the reduction in IgA didn't reach a significant level, IgG increased but the increase was statistically non significant.

Table 1: Serum immunoglobulins in newly diagnosed patients with ALL and control group.

\begin{tabular}{lccccc}
\hline & \multicolumn{2}{c}{ ALL } & \multicolumn{2}{c}{ Healthy } & \multirow{2}{*}{ SD } \\
\hline $\lg G$ & 1082.5 & 332.3 & 1156.95 & 335.11 & 0.653 \\
$\lg$ & 105 & 21.6 & 147.25 & 56.55 & 0.019 \\
$\lg A$ & 115.4 & 31.2 & 215.75 & 116.11 & 0.007 \\
\hline
\end{tabular}

Table 2: Serum immunoglobulins in newly diagnosed patients with CLL and control group.

\begin{tabular}{|c|c|c|c|c|c|}
\hline & \multicolumn{2}{|c|}{ CLL } & \multicolumn{2}{|c|}{ Healthy } & \multirow{2}{*}{$P$ value } \\
\hline & Mean & SD & Mean & SD & \\
\hline $\lg G$ & 896.2 & 394.69 & 1156.95 & 335.11 & 0.69 \\
\hline $\operatorname{lgM}$ & 61.4 & 39.64 & 147.25 & 56.55 & $<0.001$ \\
\hline $\lg A$ & 161.4 & 102.87 & 215.75 & 116.11 & 0.221 \\
\hline
\end{tabular}

Table 3: Serum immunoglobulins in newly diagnosed patients with NHL and control group.

\begin{tabular}{lccccc}
\hline & \multicolumn{2}{c}{ NHL } & \multicolumn{2}{c}{ Healthy } & \multirow{2}{*}{ Malue } \\
& Mean & SD & Mean & SD & \\
\hline $\lg G$ & 1210.3 & 502.52 & 1156.95 & 335.11 & 0.731 \\
$\lg$ & 98.5 & 54.92 & 147.25 & 56.55 & 0.033 \\
$\lg A$ & 176.2 & 82.87 & 215.75 & 116.11 & 0.346 \\
\hline \hline
\end{tabular}




\section{Hodgkin Lymphoma}

The mean concentration of each lgG, $\lg \mathrm{M}$ and $\lg \mathrm{A}$ were 1353, 97 and $197 \mathrm{mg} / \mathrm{dl}$ respectively, as it is revealed in table 4 , IgG level increased but the rise was not significant compared to control group, while IgM level reduced significantly ( $p$ < 0.05 ) compared to control group, $\lg \mathrm{A}$ decreased but not to a significant level.

\section{Multiple Myeloma}

The mean concentration of serum $\operatorname{lgG}$, $\lg M$ and $\lg A$ for ten patients with multiple myeloma were 1852, 93 and $205.5 \mathrm{mg} / \mathrm{dl}$ respectively (Table 5), IgG increased to a highly significant level, the decrease in IgM level was significant while in IgA level didn't change significantly. IgG increased to a highly significant level, the decrease in IgM level was significant while in $\lg A$ level didn't change significantly.

\section{Frequency of $M$ bands showed by} serum protein electrophoresis

Serum protein electrophoresis results showed that out of ten patients with multiple myeloma all of them $(100 \%)$ shows $M$ bands while only one patient out of ten patients with CLL and NHL (10\%) had $M$ bands, there were no $M$ bands in both ALL and HL. The M bands in ten patients with multiple myeloma have a mean value which is $3.024 \mathrm{~g} / \mathrm{dl}$ while the $\mathrm{M}$ band value in both $\mathrm{NHL}$ and CLL is 1.6 and $1.2 \mathrm{~g} / \mathrm{dl}$ respectively.

\section{Lymphoproliferative disorders}

Serum IgG levels among whole patients with lymphoproliferative disorders increased comparing to control group, but this increase was not statistically significant. By contrast, the mean concentration of serum $\lg \mathrm{M}$ and $\lg \mathrm{A}$ were lower than that of the control group, but statistically, they were non significant (Table 6).

Table 4: Serum immunoglobulins in newly diagnosed patients with $\mathrm{HL}$ and control group.

\begin{tabular}{lccccc}
\hline & & HL & \multicolumn{2}{c}{ Healthy } & \multirow{2}{*}{ SD } \\
\hline $\lg$ Mean & 1353 & 380.76 & 1156.95 & 335.11 & 0.16 \\
$\lg M$ & 97 & 39.17 & 147.25 & 56.55 & 0.018 \\
$\lg A$ & 197 & 94.61 & 215.75 & 116.11 & 0.662 \\
\hline
\end{tabular}

Table 5: Serum immunoglobulins in newly diagnosed patients with $\mathrm{HL}$ and control group.

\begin{tabular}{lccccc}
\hline & & MM & \multicolumn{2}{c}{ Healthy } & \multirow{2}{*}{ SD } \\
\hline $\lg G$ & 1852 & 1523.10 & 1156.95 & 335.11 & 0.008 \\
$\lg M$ & 93 & 65.06 & 147.25 & 56.55 & 0.026 \\
$\lg A$ & 205.5 & 198.04 & 215.75 & 116.11 & 0.859 \\
\hline
\end{tabular}

Table 6: Serum immunoglobulins in newly diagnosed patients with lymphoproliferative disorders and control group.

\begin{tabular}{|c|c|c|c|c|c|c|}
\hline \multicolumn{7}{|c|}{ Mean conc. of Serum Immunoglobulins ( $\mathrm{mg} / \mathrm{dl})$} \\
\hline Groups & $\begin{array}{c}\text { Mean } \\
\operatorname{lgG} \pm \text { SD }\end{array}$ & $\begin{array}{l}\text { C.S. by } \\
\text { t test }\end{array}$ & $\begin{array}{c}\text { Mean } \\
\operatorname{IgM} \pm \text { SD }\end{array}$ & $\begin{array}{c}\text { C.S. by } \\
\text { t test }\end{array}$ & $\begin{array}{c}\text { Mean } \\
\lg A \pm \text { SD }\end{array}$ & $\begin{array}{l}\text { C.S. by } \\
\text { t test }\end{array}$ \\
\hline $\begin{array}{l}\text { Lymphoproliferative disorders } \\
\text { (ALL, CLL, HL, NHL and MM) } \\
\text { No. }=50\end{array}$ & $\begin{array}{c}1318.5 \pm \\
805\end{array}$ & $\begin{array}{c}0.389308 \\
\text { NS }\end{array}$ & $\begin{array}{c}91.51 \pm \\
46.53\end{array}$ & $\begin{array}{c}5.765 \\
\text { N.S }\end{array}$ & $\begin{array}{c}168.9615 \pm \\
115.659\end{array}$ & $\begin{array}{c}0.124218 \\
\text { NS }\end{array}$ \\
\hline $\begin{array}{l}\text { Healthy } \\
\mathrm{Nr} .=20\end{array}$ & $\begin{array}{c}1156.95 \pm \\
335.11\end{array}$ & & $\begin{array}{c}147.25 \pm \\
56.55\end{array}$ & & $\begin{array}{c}215.75 \pm \\
116.11\end{array}$ & \\
\hline
\end{tabular}




\section{Discussion}

Most immunoglobulins are produced by mature plasma cells. ${ }^{10}$ Antibodies can occur in two physical forms, a soluble form that is secreted from the cell, and a membrane-bound form that is attached to the surface of a $B$ cell and is referred to as the $B$ cell receptor (BCR). The BCR is only found on the surface of $B$ cells and facilitates the activation of these cells, and their subsequent differentiation into either antibody factories called plasma cells or memory B cells that will survive in the body and remember that same antigen so the $B$ cells can respond faster upon future exposure. ${ }^{11}$ Hematologic malignancies can be associated with dysregulation of the immune system. There are some conflicting data regarding serum immunoglobulin levels in patients with such malignancies. ${ }^{8}$ A number of studies revealed various qualitative and quantitative defects in the production of the immunoglobulins, $T$ and $B$ lymphocytes activities, number and function of macrophages and neutrophils including chemotaxis, phagocytosis and also aberrations of complement system. ${ }^{12}$ Low levels of one type or more of immunoglobulin were frequently found in this study. The suppression of immunoglobulin was mild, this finding has repeatedly been reported by other workers ${ }^{13}$ and has been associated with advanced disease This immunosuppression is related to decreased $\mathrm{lg}$ production resulting from B-cell depletion due to the replacement of lymphoid tissue or due to the effect of treatment ${ }^{14,15}$ or as a result of malnutrition. Other postulated mechanisms of hypogammaglobulinemia include intrinsic Blymphocyte defects ${ }^{16-19}$ or defective regulatory function of T-cells or monocytes ${ }^{18}$.In some patients with hypogammaglobulinemia, the obvious failure of seemingly normal B-cells to differentiate into plasma cells that synthesize and secrete $\mathrm{Ig}$ is still not completely understood. ${ }^{20}$ Reduced serum $\lg G$ was observed in the studied patients with $A L L$, and this reduction didn't reach significant level, such results are in agreement with those obtained by Okpala and Salimonu who have shown decreased lgG level and raised immune complexes in acute lymphoblastic leukemia. Decreased IgG and raised immune complex levels to reduce the ability to mount immune responses and therefore imply bad prognosis. ${ }^{21}$ Other workers have reported high immunoglobulin levels in newly diagnosed ALL patients. ${ }^{8,9}$ Lower survival rate has been shown in patients with higher $\operatorname{lgG}$ level ${ }^{22}$ while it has been found that patients with low IgG levels have an increased mortality rate, ${ }^{24}$ the prognostic value of IgG level in ALL has been controversial. ${ }^{23}$ In the present study, the low level of serum IgA was also most commonly observed in newly diagnosed ALL patients as compared to control group; this reduction was highly significant. This might indicate suppressed antibodies production by B-lymphocytes in response to tumor antigen ${ }^{23}$. In previous studies, large number of patients showed a decrease in one or more immunoglobulins level. ${ }^{24}$ It is suggested that the reduced immunoglobulin levels observed in these patients are due to decreased normal immunoglobulin-producing lymphocytes. ${ }^{25}$ Chronic lymphocytic leukemia (CLL) is characterized by the progressive accumulation of monoclonal lymphocytes with a distinctive immunophenotype (i.e., CD5+, CD19+, CD20dim,CD23+, Smlgdim) in peripheral blood, bone marrow, and lymphoidtissues. ${ }^{26,27} \mathrm{~B}-\mathrm{CLL}$ is frequently accompanied by decreased levels of serum immunoglobulins which increases patients susceptibility to infections. Low levels of $\lg A$, IgM and IgG occur in $30 \%, 30 \%$ and $10 \%$ of B-CLL patients respectively at the time of diagnosis. The appearance of decreased levels of immunoglobulins is a continuous process developing spontaneously during the untreated course of the disease. As the clinical stage of the 
disease advances, there is a trend for a more frequently decreased levels of immunoglobulins. ${ }^{28}$ In the current study, the mean value of all immunoglobulin subclasses (IgM, $\lg G$ and $\lg A$ ) were decreased but only the reduction in IgM level reached a highly significant level, this is in concordance with the results reported by $\mathrm{Natasa}^{28}$ (2001). Decreasing more frequently depressed in CLL than $\operatorname{lgG}$ (30, 30 and $10 \%$ of patients respectively), both at the time of diagnosis and during the evolution of the disease. ${ }^{29} \mathrm{~B}-\mathrm{CLL}$ cells play a direct role in $\mathrm{lg}$ production, they have found that B-CLL cells inhibit the spontaneous $\lg$ secretion by bone marrow plasma cells in coculture of bone marrow immunoglobulin secreting cells with autologous B-CLL cells. ${ }^{30}$ One of ten of studied CLL patients had an $M$ band; this finding has been observed by other workers. M-protein secretion is typically a feature of plasma cell dyscrasias; it can be detected with varying frequencies in other B-cell malignancies such as chronic lymphocytic leukemia (CLL) or non-Hodgkin lymphoma $(\mathrm{NHL}){ }^{31}$ The alterations of cellular and/or humoral immunity in $\mathrm{NHL}$ patients are not uncommon. ${ }^{32}$ This study shows that there was a decrease in serum levels of both IgM and IgA in patients with NHL while the level of IgG was increased but did not reach a significant level. In agreement with this study, two reports showed that $\operatorname{lgM}$ and IgA were also decreased in patients with $\mathrm{NHL}^{32,33}$ lgG levels were not decreased in one study, ${ }^{32}$ but in contrast, it was decreased in other studies, ${ }^{33}$ while a study ${ }^{34}$ showed no increase in IgG levels, and lower IgG levels in NHL patients was observed. ${ }^{33,34}$ Levels of all immunoglobulin class were decreased in $\mathrm{NHL}$ patients. Another study which supports our results demonstrated that the most frequent hypoimmunoglobulinaemia is in class $\operatorname{lgM}$ (22\%), followed by $\operatorname{lgA}(8 \%){ }^{35,36}$ In $\mathrm{NHL}$ patients intrinsic B-cell defects, increased T-cell or monocyte suppressor activity, and diminished T-helper activity may also contribute to the hypogammaglobulinaemia. ${ }^{37-39}$ One of ten studied patients with $\mathrm{NHL}$ had an $M$ band, this has been reported by other worker. ${ }^{40}$ Patients with HL have a well-described cellular immune deficiency, which is based on clinical and laboratory findings. ${ }^{41}$ The underlying immune deficiency may be congenital or acquired with an increased incidence of $\mathrm{HL}$ in patients with combined variable immune deficiencies and human immunodeficiency virus (HIV) infection ${ }^{42}$ or may be related to the disease itself. ${ }^{43}$ The most frequent hypoimmunoglobulinaemia is in class $\lg \mathrm{M}$ $(22 \%)$, followed by class IgG $(11 \%)$ and IgA $(8 \%) .{ }^{36}$ In present study $\lg M$ was decreased significantly, the reduction in IgA level didn't reach significant level while IgG level was increased but insignificantly, reduction of $\operatorname{lgG}$ without significant differences. ${ }^{44}$ Elevated IgG has been reported by other author. ${ }^{32,33}$ Normally plasma cells constitute $1 \%$ in the bone marrow but as the disease advances, tumor load in bone marrow increases up to $80 \%$ depending on severity. These malignant plasma cells synthesize monoclonal antibody and release it to the circulation. As a result, a high concentration of monoclonal antibodies is present in bone marrow as well as in serum. ${ }^{45}$ Highly significant increase in serum levels of IgG was observed in MM patients in this study; this is similar to the results reported by another study. ${ }^{45}$ Similar results have been observed by Harousseau and Dreyling, they noticed that in most cases of multiple myeloma, there is a malignant proliferation of plasma cells producing IgG. ${ }^{46}$ Even though the mean $\lg G$ level was higher than other immunoglobulin classes in our study, it was still in the normal range this one in concordance with other previous study which was done by another study. ${ }^{8}$ While the levels of both IgM and IgA were decreased and $100 \%$ of patients showed $M$ bands in this study and it is in concordance with the results reported by 
another study, ${ }^{42}$ when he observed that the reduction of uninvolved immunoglobulins is common. An M-protein was found in the serum or urine or both in $97 \%$ of patients with multiple myeloma at the time of diagnosis. Three percent of the patients had no M-protein in the serum or urine and were designated as having nonsecretory myeloma. Hypogammaglobulinemia $(<0.7$ $\mathrm{g} / \mathrm{dL}$ ) was found in $8 \%$ of patients, and the pattern was normal appearing in $11 \% .{ }^{42}$ $T$ cell and $B$ cell abnormalities in peripheral blood populations of myeloma patients have been reported by a number of investigators. However, it is not clear if these abnormalities are involved with the development of the disease or are a result of the disease process. ${ }^{47}$

\section{Conclusion}

There are conflicting data of serum immunoglobulin levels in newly diagnosed patients with lymphoproliferative disorders, IgA and IgM levels were reduced significantly in ALL cases, IgM level reduced significantly in CLL, NHL and MM patients while IgG level among whole patients with lymphoproliferative disorders was higher than that of the control group.

\section{Conflicts of interest}

The authors report no conflicts of interest.

\section{References}

1. Jemal A, Siegel R, Ward E, Murray T, Xu J, Smigal C, et al. Cancer statistics. CA Cancer J Clin 2006; 56:106-30.

2. Kaushansky K, Lichtman M, Kipps T, Seligsohn U, Prchal J. Williams Hematology. $8^{\text {th }}$ ed. New York: McGraw-Hill; 2010. p. 272-98.

3. Malik AR, Tayyib M, Tasnim T, Ditta A, Chaudhary NA. Serum immunoglobulin levels in patients with non-Hodgkin's lymphoma. Pak Postgrad Med J 2002; 13(3):114-9.

4. Raab MS, Podar K, Breitkreutz I. Multiple myeloma. Lancet 2009; 374:324-9.

5. Martins G, Calame K. Regulation and functions of Blimp-1 in T and B lymphocytes. Annu Rev Immunol 2008; 26:133-69.

6. Kiani-amin $M$, Daneshi M, Ayazi $P$, Mohammadian Sh, Rezaeiz N. Serum immunoglobulin levels in splenectomized and non-splenectomized patients with major beta-Thalassemia. Iran J Pediatr 2011; 21(1):95-8.
7. Amin $A$, Jalali $S$, Amin R. Evaluation of the serum levels of immunoglobulin and complements factors in Beta thalassemia major patients in southern Iran. Iran J Immunol 2005; 2(4):220-5.

8. Mashhadi MA, Khazaei HA, Narouie B, Niazi AA, Moazzami K, Khademi R, et al. Abnormal immunoglobulin levels in Iranian patients with hematologic malignancies. Shiraz E Medical Journal 2009; 10(3):120-5.

9. Martin I, Arce A, Cruz O, Estella J, Martín MA. Humoral immunity in pediatric patients with acute lymphoblastic leukaemia. Allergollmmunopathol (Madr) 2003; 31 (6):303-10.

10. Shimizu Y, Hendershot LM. Organization of the functions and components of the endoplasmic reticulum. Adv Exp Med Biol 2007; 594:37-46.

11. Borghesi L, Milcarek C. From B cell to plasma cell: regulation of $\mathrm{V}(\mathrm{D}) \mathrm{J}$ recombination and antibody secretion. Immunol Res 2006; 36(1-3):27 $-32$.

12. Ahluwalia J, Datta U, Marwaha RK. Immune function in splenectomized thalassemic children. Indian J Pediatr 2002; 67(12):871-6.

13. Parker D, Alison DL, Barnard DL, Child JA, Dovey G, Farish J, et al. Prognosis in low grade non-Hodgkin's lymphoma: relevance of the number of sites involved, absolute lymphocyte count and serum immunoglobulin level. Hematol Oncol 1994; 12(1):15-27.

14. Winkelstein A. Differential effects of immunosuppressants on lymphocyte function. J Clin Invest 1973; 52:2293-9.

15. Stevenson HC, Fauci AS. Immunosuppression Secondary to Pharmacologic Agents: Primary and Secondary Immunodeficiency Disorder. New York: Churchill Livingston; 1983.

16. Fauci AS, Pratt KR, Whalen G. Intrinsic B-cell defect in the immunoglobulin deficiency of chronic lymphocytic leukemia (Abstr). ClinRes $1977 ; 25: 482$.

17. Han T, Dadey B. In vitro functional studies of mononuclear cells in patients with CLL Evidence for functionally normal T-lymphocytes and monocytes and abnormal B-lymphocytes. Cancer 1979; 43:109-17.

18. Hersey P, Wotherspoon J, Reid G, Gunz FW. Hypogammaglobulinemia associated with abnormalities of both B- and T-lymphocytes in patients with chronic lymphocytic leukemia. Clin Explmmunol 1980; 39;698-707.

19. Lamberson HV, Davey FR, Schreck CM, Zamkoff K, Kurec AS .Lymphocyte response to pokeweed mitogen in chronic lymphocytic leukemia. Cancer 1984; 53:2481-6.

20. Pereira RS, Platts-Mills TAE. Lymphocyte subsets in hypogammaglobulinemia. Clin Hematol 1982; 1:1589-605.

21. Okpala IE, Salimonu LS. The prognostic value of serum Immunoglobulin $\mathrm{G}$ and immune complex levels in acute lymphoblastic leukemia. Cent Afr J Med 1991; 37:153-6. 
22. Potapnev MP, Belevtsev MV, Bortkevich LG, Grinev VV, Martsev SP, Kravchuk Zl, et al. Significance of serum immunoglobulin $G$ for leukocytosis and prognosis in childhood B-lineage acute lymphoblastic leukemia. Pediatr Blood Cancer 2004; 42(5):421-6.

23. Sorensen RU, Moore C. Antibody deficiency syndromes. Pediatr Clin North Am 2000; 47:122552.

24. Davies EG .Immunodeficiency. In: Campbell AGM, Mc Intosh N (Eds). Textbook of Pediatrics. $5^{\text {th }}$ ed. New York: Livingstone; 1989. P. 1231- 70.

25. Leikin S, Miller D, Sather H, Albo V, Esber E, Johnson A. Hammond D. Immunologic evaluation in the prognosis of acute lymphoblastic leukemia. A report from Childrens Cancer Study Group. Blood 1981; 58(3):501-8.

26. Swerdlow S. International Agency for Research on $\mathrm{C}$, World Health $\mathrm{O}$. WHO classification of tumours of haematopoietic and lymphoid tissues. 4th ed. Lyon France: International Agency for Research on Cancer; 2008.

27. Hallek M, Cheson BD, Catovsky $D$, Caligaris-Cappio F, Dighiero G, Döhner H, et al. Guidelines for the diagnosis and treatment of chronic lymphocytic leukemia: areport from the International Workshop on Chronic Lymphocytic Leukemia updating the National Cancer Institute-Working Group 1996 guidelines. Blood 2008; 111(12):5446-56.

28. Natasa E, Andrija B, Vesna M, Gradimir J. Prognostic significance of serum immunoglobulins in B-chronic lymphocytic leukemia. Arch Oncol 2001; 9(2):79-82.

29. Rozman C. Montserrat E, Rodríguez-Fernández JM, Ayats R, Vallespí T, Parody R, Ríos A, Prados D, Morey M, Gomis F. Bone Marrow Histologic Pattern-The Best Single Prognostic Parameter in Chronic Lymphocytic Leukemia: A Multivariate Survival Analysis of 329 Cases. Blood 1984; 64(3): 642-8.

30. Sampalo A, Navas G, Medina F, Segundo C, Camara C, Brieva AJ. Chronic lymphocytic leukemia B cells inhibit spontaneous Ig production by autologous bone marrow cells: role of CD95CD95L. Blood 2000; 96:3168-74.

31. Pezzoli A, Pascali E. Monoclonal Bence Jones proteinuria in chronic lymphocytic leukaemia. Scand J Haematol 1986; 36:18- 24.

32. Ellison-Loschmann L, Benavente Y, Douwes J, Buendia E, Font R, Alvaro T, et al. Immunoglobulin $E$ levels and risk of lymphoma in a case-control study in Spain. Cancer Epidemiol Biomarkers Prev 2007; 16:1492-8.

33. Grulich AE, Vajdic CM, Riminton S, Hughes AM, Kricker A, Armstrong BK et al. Re: atopy and risk of non-Hodgkin lymphoma. J Natl Cancer Inst 2007; 99:1417-22.

34. Robert J. Biggar, M C, Klaus R, Karin E. Immunoglobulin subclass levels in patients with non-Hodgkin lymphoma. Int J Cancer 2009;
124: $2616-20$.

35. Biggar RJ, Christiansen $M$, Rostgaard $\mathrm{K}$, Smedby KE, Adami HO, Glimelius B, et al. Immunoglobulin subclass levels in patients with non-Hodgkin lymphoma. Int J Cancer 2009; 124:2616-20.

36. Ana $\mathrm{P}$, Koloni $\mathrm{S}$, Radi-Krito D, Dominis $\mathrm{M}$, Branimir J. Serum Immunoglobulins in nonHodgkin's Lymphoma Patients. Coll. Antropol 2010; 34(2):407-11.

37. Martin W, Abraham R, Shanafelt T, Clark RJ, Bone N, Geyer SM, et al. Serum-free light chain-a new biomarker for patients with B-cell nonHodgkin lymphoma and chronic lymphocytic leukemia. Translational Research 2007; 149:2315.

38. Melbye M, Smedby KE, Lehtinen T, Rostgaard K, Glimelius B, Munksgaard L, et al. Atopy and risk of non-Hodgkin lymphomaJ Natl Cancer Inst 2007; 99:158-66.

39. Ostojic-Kolonic S, Prasek-Kudrna K, Roso V, Radic-Kristo D, Planinc- Peraica A, Dzebro S, et al. Value of fine-needle aspiration cytology in diagnosis of Hodgkin's lymphoma and anaplastic large cell lymphoma: one centre experience. Coll Antropol 2010; 34:75-9.

40. Pascali E, Pezzoli A. The clinical spectrum of pure Bence Jones proteinuria. A study of 66 patients. Cancer 1988; 62:2408-15.

41. Kennedy-Nasser AA, Bollard CM, Rooney CM. Adoptive immunotherapy for Hodgkin's lymphoma. Int J Hematol 2006; 83:385-90.

42. Robert A, Morie A, Thomas E, John A, Martha Q , Angela D, et al. Review of 1027 Patients With Newly Diagnosed Multiple Myeloma. Mayo Clin Proc 2003; 78:21-33.

43. Poppema S, Potters M, Visser L, Van Den B. Immune escape mechanisms in Hodgkin's disease. Ann Oncol 1998; 9(Suppl 5):S21-4.

44. Obianwu I, Onykwere T, Ochene S. Immunoglobulin level in some myeloproliferative and lymphoproliferative disorders in Enugu, Nigeria. Research Journal of Medical Sciences 2007; 1(2):132-4.

45. Nepal AK, Shakya PR, Gelal B, Lal Das BK, Shrestha BP, Lamsal M, et al. Biochemical profile of Multiple Myeloma in the patients visiting bpkihs as diagnosed by agarose gel electrophoresis. Health Renaissance 2010; 8 (2):122-5.

46. Harousseau JL, Dreyling M. Multiple myeloma: ESMO clinical recommendations for diagnosis, treatment and follow-up. Ann Oncol 2009; 20(Suppl 4):97-9.

47. Mills KHG, Cawley JC. Abnormal monoclonal antibody-defined helper/suppressor $\mathrm{T}$ cell populations in niultiplc myeloma. Relationship to treatment and clinical stage. Br J Haematol 1983; S3:271-4. 